Mr. Balfour has said, have " slowly grown up under the moulding influence of circumstances, acting from generation to generation "; and the surest way of disheartening a University, and " chequering" its future history, is to exacerbate the feelings of its graduates by depriving them of a cherished privilege.

The immediate question is whether some modification of the proposals of the Speaker's Conference is practicable which would not break down the compromise accepted by both political parties. Sir Philip Magnus, Sir William Collins, and Mr. M'Kinnon Wood (all of whom are London graduates), Sir James Yoxall, Mr. Fell, and Mr. George Faber, have put down an amendment to the Bill providing that the University of London shall return one member, and that the other Universities of the proposed group shall form a constituency returning three members. If accepted, this arrangement would mean an increase of one in the total number of University representatives, eleven instead of ten contemplated by the Speaker's Conference. It is expected that the amendment will be moved in the course of a few days. We hope the amendment will be adopted, thus repeating the history of fifty years ago, when a proposal to join London to another University to form a constituency was defeated against the Government, and London obtained the privilege of separate representation which it has since enjoyed.

T. LL. Humberstone.

\section{THE EDUCATION BILL.}

THE history of the measures for reform and improvement in the means and methods of education introduced into the House of Commons since the passing of the Education Act of rgo2, which did so much for advanced education and to increase the public responsibility for all forms of education, has been one long tale of disaster; and Minister after Minister has succumbed to the opposition his measures have provoked.

It would seem, judging by the announcement made by $\mathrm{Mr}$. Bonar Law in the House of Commons on October I9, that the same doleful fate awaits the Bill brought in by $\mathrm{Mr}$. Fisher on August 13 last with such favourable omens. The personality of Mr. Fisher, his known deep interest in the subject, the sound knowledge and experience he has brought to bear upon it, together with the lucid and interesting exposition of the details of his measure, have won for it wide and favourable recognition and a strong body of support, due no doubt to those clauses of the Bill which have for their object the welfare of the child, whether in the condition of infancy or throughout the years of adolescence, so as to secure for the child the fullest opportunity of effective moral, intellectual, and physical training.

The advent and circumstances of the war have awakened amongst all classes of the people, employers and employed alike, a deeper sense of the value of education and of the responsibility of the nation for the adequate preparation of the children for the duties that await them. It has at last been brought home to those engaged in industry and commerce that Germany's position as a formidable rival is wholly due to the splendid facilities she has provided for the due training of her people, and that successful competition with her can be assured only by the adoption of a similar policy. Grave questions of reconstruction are under consideration, but they can be assured of their desired effect only in so far as they appeal to an educated people. The increasing industrial applications of scientific discovery demand a higher range of intelligence amongst all classes, and it is no less important for the well-being of the nation that the ampler leisure now urgently sought should be wisely used and enjoyed-a condition possible only where the means and opportunity of an efficient education exist. The ravages of the war, which has taken so huge a toll of educated young life, furnish another admittedly grave reason why we should at once make provision for the adequate education of all our youth.

Let it be remembered that $\mathrm{Mr}$. Fisher was called from a position of high educational distinction in order that he might bring the ripe fruit of his knowledge and experience to bear upon the problem of ensuring the means of a more efficient education for the people of this country, and that it is little short of a cruel irony to refuse him the necessary time for the full consideration of his proposals. It is true that there are grave objections to some of the administrative clauses of the Bill, especially those which tend to increase the bureaucratic power of the Board of Education, but they are not of the essence of the measure, and may with advantage be taken out of the Bill. As to the threatened opposition of the textile industry, the only answer there can be is that the interests of the child are paramount. It should be possible to arrange upon an agreed measure, so far as the educational clauses are concerned, and so satisfy the ardent desire of the great majority of the people that such a measure should pass into law. There are strong reasons why further time should not be lost, since before the educational proposals embodied in the Bill can have their desired effect there is much to be done in the provision of teachers, equipment, and suitable buildings.

\section{PROF. EDWARD HULL, F.R.S.}

DROF. EDWARD HULL, who died in London on October 18, was born at Antrim, where his father was rector, on May 2r, I829, and had thus reached his eighty-ninth year. Like many of those whose work has lain in the open air, he retained considerable vigour, anc he revisited at the age of eighty some of the scenes of his early observations. His father proposed for him a career in the Church of Ireland, and his early literary and biblical studies no doubt left an impression on his life. Attracted, however, by

NO. 2505 , VOL. IOO] 
experimental science, Hull entered Dublin University as a student of engineering, and the lectures of Thomas Oldham determined his career. Oldham recommended him to De la Beche, and he was appointed to the English Geological Survey as assistant to $J$. Beete Jukes.

These names serve to link Hull with the pioneers of British stratigraphy, and it was Murchison who nominated him in 1869 to succeed Jukes as director of the Geological Survey of Ireland. In his " Reminiscences of a Strenuous Life" (I9I0), reviewed in NAture, vol. Ixxxiii., p. 395, interesting details are given of scientific life in Dublin when he entered on his new duties. In the same year he became professor of geology in the Royal College of Science for Ireland.

The series of sheets of the one-inch geological map of Ireland, already well advanced by Jukes for the southern area, was pushed forward by Hull with such prevision that the first issue was completed by the date of his retirement in 1890 . Some of the revisions made in Jukes's work may be regarded as unfortunate; but the northern sheets, with their admirable choice of colouring, remain as a monument to Hull's powers of organisation. $\mathrm{He}$ was probably the first to utilise the petrological microscope as an aid to research in an official survey ("Memoir to Sheet 48 , "Ireland, 1872), and thus laid the foundation for much memorable work.

Hull's first published paper was on the Cotswold Hills in 1855 , and was succeeded by more than I 50 others. Much of his time on the survey of England and of Scotland was spent on Carboniferous areas, and his book on "The Coalfields of Great Britain" reached a fifth edition in r905. $\mathrm{He}$ was a member of the Royal Commissions on Coal Supplies in r $87 \mathrm{r}$ and Igor. As the result of a journey on behalf of the Palestine Exploration Fund, he published a narrative volume (1884) and a geological memoir on Palestine (1886). His "Physical Geology and Geography of Ireland" (1878; 2nd ed. 1891) and "The Building, and Ornamental Stones of Great Britain, etc.," are well-known treatises. A good portrait of Hull occurs in the "Reminiscences" above mentioned.

\section{NOTES.}

THE late Mr. Cawthron left 250,00ol. to the city of Nelson, New Zealand, for scientific research. The trustees are the Bishop of the diocese, the member for the district, the Mayor of Nelson, two chairmen of local bodies, and a personal friend of the deceased. The site of the proposed institute has been purchased, and the appointment of a director and staff is under consideration. The object of the institute is, primarily, scientific research work for the benefit of the province of Nelson and the Dominion of New Zealand. The province of Nelson is mostly concerned with fruit, agriculture, and minerals.

UNDER the title of "Science and Industry," the Evening Standard has recently published a series of five articles discussing the bearing of applied chemistry in its various branches on the welfare and safety of the nation. The national importance of chemical manufacture lies in the circumstance that so many NO. 2505 , VOL. IOO] undertakings included in this category are key industries, representing vulnerable points in the commercial armour of a nation. For instance, in a country deprived of its supply of sulphur, the manufacture of sulphuric acid would at once cease. This stoppage would react immediately on the production of alkalis, and these in turn would affect the output of soap and glycerine, which would not be obtainable. Without sulphuric acid, the manufacture of nitric acid from nitre could not be continued, and the production of explosives would be brought to a standstill. In this way whole sections of commercial activity would be completely dislocated, and the nation would be left practically defenceless. A similar line of reasoning shows that the manufacture of synthetic dyes is also a key industry. These chemical industries have all developed from researches often carried out, in the first instance, merely out of scientific curiosity. In fact, nearly all the more important and revolutionary advances in industrial chemistry have sprung fromi pure research, although utilitarian researches carried out on special lines have contributed minor improvements. The former type of research should be subsidised by the State, whereas the latter should be maintained by the manufacturers. Scientific men, who have shown undoubted aptitude for the all-important pure research, have often to pretend that their investigations have a quasi-industrial bent in order to justify their activities in the eyes of departmental donors. The writer of the articles in our contemporary asserts that in the difference between England and Germany as regards the development of science and industry "there is no question of superior intellect or greater technical skill or a more suitable national temperament," but he also blames the nation as a whole for the lack of progress in industry based on chemical science. Surely what is lacking in the nation is the inspiration of a lofty ideal. In actual practice honour and public esteem come to him who acquires most wealth, and the choice of a profession is regarded merely as a means to this end. As the German scientific industrialist, von Rathenau, has recently pointed out, this is not the sole end in view of the many hundreds of chemists and other investigators who discover and improve the scientific processes of manufacture which are the most valuable assets of the German chemical monopolies.

Dr. Otтo KLotz has been appointed Chief Astronomer and Director of the Dominion Astronomical Observatory at Ottawa.

THE death is announced, on October 27, of $\mathrm{Mr}$. Worthington G. Smith, of Dunstable, fellow of the Linnean and other societies, at eighty-two years of age.

WE notice with regret the announcement of the death on October 24, at fifty-four years of age, of $\mathrm{Mr}$. George T. Holloway, vice-president of the Institution of Mining and Metallurgy, and widely known as a consultant metallurgist and assayer.

A course of twelve Swiney lectures on geology will be delivered by Dr. J. S. Flett at the Royal Society of Arts on Tuesdays, Thursdays, and Fridays, beginning on Tuesday, November 13 . The subject will be "The Mineral Resources of the British Empire." No charge for admission will be made.

WE notice with much regret the announcement that Baron Dairoku Kikuchi died suddenly at his villa at Chigasaki, Japan, on August 19. Baron Kikuchi was formerly professor of mathematics in the Imperial University at Tokyo, and afterwards its president. He was the author of many contributions to scientific 